związanych. Chodziło mianowicie o to, że S. Czerwińskiego - ewangelika pochowano w obrządku rzymsko-katolickim. Śmierć tego zasłużonego pedagoga i działacza zaskoczyła nie tylko środowisko oświatowe, ale i znaczą część społeczeństwa polskiego.

W ostatnim, piątym rozdziale pt. „Przejawy pamięci” (s. 78-80) Autor podaje, że jednym z pierwszych przejawów pamięci było uhonorowanie S. Czerwińskiego przez prezydenta Ignacego Mościckiego Wielką Wstęgą Orderu Odrodzenia Polski - za wybitne zasługi dla oświaty. Pamięć ministra została także uczczona podczas posiedzenia sejmu w 1931 r. Imię S. Czerwińskiego noszą także ulice, np. w Ostrowcu Świętokrzyskim oraz kilka szkół w Polsce (np. Szkoła Podstawowa nr 11 w Kaliszu). W 1932 r. Polska Marynarka Wojenna także nadała okrętowi imię ORP „Sławomir Czerwiński”.

Jak stwierdza sam Autor w „Zakończeniu” (s. 81-82) praca nie wyczerpuje całości wiedzy na temat ministra S. Czerwińskiego, a jest jedynie pewnym zasygnalizowaniem tematów zasługujących na zgłębienie. Na szczególną uwagę zasługuje fakt, że Autor w swej publikacji zgromadził wiele fotografii pochodzących ze zbiorów: Archiwum Państwowego w Krakowie, Archiwum Uniwersytetu Jagiellońskiego w Krakowie, Narodowego Archiwum Cyfrowego, Stowarzyszenia Wychowanków Gimnazjum i Liceum im. Asnyka w Kaliszu, Kaliskiego Towarzystwa Przyjaciół Nauk, Biblioteki Sejmowej w Warszawie, Książnicy Pedagogicznej im. A. Parczewskiego w Kaliszu, a także publikowanych na łamach „Cyrulika Warszawskiego”, znajdujących się w prywatnych zbiorach i witrynach internetowych. Oddana do rąk czytelnika książka jest formą oddania hołdu zasłużonemu ministrowi - S. Czerwińskiemu i jego pracy na rzecz polskiej oświaty. Spełnia także funkcje popularyzacji wiedzy o zasłużonych Polakach lat międzywojennych pracujących na rzecz oświaty polskiej.

Joanna Falkowska

\title{
Wychowanie $w$ rodzinie. Przekaz tradycji i kultury na przestrzeni wieków, tom 1, red. S. Walasek, L. Albański, Wydawnictwo: Karkonoska Państwowa Szkoła Wyższa w Jeleniej Górze, Jelenia Góra 2011, ss. 276
}

Historycy wychowania Instytutu Pedagogiki Uniwersytetu Wrocławskiego oraz pedagodzy Wydziału Humanistycznego Karkonoskiej Państwowej Szkoły Wyższej w Jeleniej Górze powołali serię wydawniczą pod tytułem „Wychowanie w rodzinie”. Jej ideą jest stworzenie interdyscyplinarnej płaszczyzny do wymiany poglądów, prezentowania wyników badań, proponowania praktycznych rozwiązań problemów dotyczących rodziny. Inicjatorzy serii pragną więc, na łamach kolejnych tomów, zaprezentować wielowymiarowy obraz rodziny, „malowany” przez reprezentantów różnych dyscyplin naukowych, z krajowych i zagranicznych ośrodków naukowych.

Pierwszy tom wspomnianej serii stanowi, wydana w roku 2011, praca Wychowanie w rodzinie. Przekaz tradycji i kultury na przestrzeni wieków pod redakcją Stefanii Wala- 
sek i Leszka Albańskiego. Jest ona częściowo plonem I Międzynarodowej Konferencji, zorganizowanej w maju 2010 r. w Jeleniej Górze i Szklarskiej Porębie, której hasło przewodnie brzmiało: „Wychowanie w rodzinie. Konteksty historyczne i współczesne”. Publikacja rozpoczynająca serię wydawniczą dotyczącą problematyki rodziny prezentuje więc przedmiot (czy raczej podmiot) swych zainteresowań w perspektywie historycznej.

Praca została uporządkowana tematycznie i podzielona na cztery części. W pierwszej zamieszczono artykuły przedstawiające wychowanie w rodzinie szlacheckiej i ziemiańskiej; druga zawiera opisy wychowania w rodzinie chłopskiej; w trzeciej przedstawiono rodzinę w wielokulturowym społeczeństwie XIX i XX w.; natomiast część czwarta prezentuje rodzinę w świetle poglądów działaczy politycznych i społecznych oraz wspomnień.

W pierwszej części recenzowanej książki - jak już wspomniano wcześniej - autorzy artykułów opisują ideały, wzorce, metody i oddziaływania wychowawcze w rodzinie szlacheckiej i ziemiańskiej na przestrzeni XVI-XIX w. Marie Marečkowa przedstawia rolę kobiet i mężczyzn w rodzinach mieszczańskich. Edyta Kahl analizuje pedagogiczne rozważania, m.in. M. Reja, A. F. Modrzewskiego, S. Petrycego czy A. M. Fredry nad modelem wychowania szlacheckiego. Barbara Ciupińska i Jan Ryś wskazują na rolę rodziny szlacheckiej w wychowaniu wojskowym i praktycznym przygotowaniu do służby wojskowej. Aneta Bołdyrew przedstawia przemiany modelu rodzinnego ziemian w XIX i na początku XX w., będące wynikiem utraty przez Polskę niepodległości, ale także popularyzacji poglądów zachodnioeuropejskich pedagogów.

W kolejnym opracowaniu Kazimierz Puchowski cofa się do wcześniejszego okresu. Opisuje bowiem wychowawcze i edukacyjne cele teatrów szkolnych prowadzonych przy zakonnych kolegiach na przestrzeni XVI-XVIII w. Wskazuje głównie na dokonania jezuitów w obszarze edukacji nowożytnych elit politycznych, lecz jednocześnie nie zataja pewnych uchybień w ich działalności.

Justyna Gulczyńska przenosi czytelnika w czasy bliższe współczesności. Omawia wpływ wychowawczy władzy państwowej PRL na młodzież szkół średnich ogólnokształcących. Autorka analizuje założenia i sposób realizacji kolejnych reform oświatowych w latach 1945-1989. Działania te określa jednoznacznie jako obsesję wychowania ideologicznego.

Artykuł Teresy Jaroszuk przybliża natomiast wychowawczą i poznawczą wartość książek zgromadzonych w polskich bibliotekach szkolnych w okresie międzywojennym. Zwraca przy tym uwagę na istniejącą rozbieżność między spisami książek obowiązkowych i zalecanych do użytku szkolnego przez Ministerstwo Wyznań Religijnych i Oświecenia Publicznego a rzeczywistym stanem i zawartością szkolnych księgozbiorów, uwarunkowanych ówczesną sytuacją polityczno-ekonomiczną.

Problematyka nierówności społecznych w oświacie, badana wielokrotnie w minionych kilkudziesięciu latach, wciąż pozostaje aktualna. Doniesienie z przeprowadzonych współcześnie badań nad działalnością nauczycieli w zakresie wyrównywaniem szans edukacyjnych uczniów ze środowisk wiejskich przedstawiła Justyna Miko-Giedyk. Zagadnienie omówiła na przykładzie powiatu kieleckiego.

Część pierwszą publikacji zamyka prezentacja badań Iwony Gumowskiej nad związkiem typu oporu uczniów wobec szkoły jako instytucji z ocenianiem rówieśników w sy- 
tuacjach szkolnych. Autorka analizuje utrwalone sposoby reagowania uczniów w sytuacjach postrzeganych przez nich jako ograniczenie lub przeszkoda narzucona przez instytucje w powiązaniu ze skłonnością do powielania stereotypów i uprzedzeń.

W drugiej części recenzowanej książki poruszono ważne problemy z zakresu teorii i praktyki pedagogiki specjalnej. Autorką dwóch artykułów z tego działu jest Danuta Apanel. W jednym wprowadza czytelnika z problematykę kształcenia integracyjnego, przedstawia jego tradycyjne i współczesne modele w Polsce i na świecie. W drugim natomiast szeroko omawia zagadnienie dysleksji i innych specyficznych trudności w uczeniu się - ich rodzaje, objawy, przyczyny. Zwraca uwagę na ogromne znaczenie właściwie i wcześnie postawionej diagnozy oraz wielospecjalistycznej terapii dla przyszłości dzieci ze specjalnymi potrzebami edukacyjnymi.

Barbara Moraczewska przedstawiła historyczny rozwój terapii zajęciowej oraz jej aktualne zastosowania w rehabilitacji osób z niepełnosprawnością. Wykazała również, że zinstytucjonalizowanie od roku 1991 tej formy terapii, w postaci Warsztatów Terapii Zajęciowej, przynosi współcześnie korzyści społeczeństwu i rodzinom osób niepełnosprawnych. Przede wszystkim jednak przyczynia się do podnoszenia jakości życia samych jednostek z niepełnosprawnością.

Kolejne opracowanie, autorstwa Anny Szczepaniak, wskazuje na związek między lękiem rodziców o przyszłość ich dzieci z niepełnosprawnością intelektualną a doświadczanym przez nich wsparciem społecznym. Autorka stwierdza, że tylko rodzice przekonani o dobrym funkcjonowaniu tego systemu mogą pozytywnie myśleć o przyszłości swoich dzieci.

Jedną z form opieki nad osobami niepełnosprawnymi, poważnie chorymi, cierpiącymi opisuje Iwona Cymerman. Prezentuje koncepcję ks. Luigi Novarese, który w oparciu o osobiste doświadczenie choroby oraz przeżycia religijne, stworzył Centrum Ochotników Cierpienia (nazywane też Apostolatem Zbawczego Cierpienia). Jego zamysłem było podkreślenie wartości i godności osób cierpiących przez wskazanie im możliwości pełnienia roli opiekunów duchowych wobec innych chorych lub zdrowej części społeczeństwa.

Na końcu części drugiej zamieszczono rozważania Agnieszki Dul nad barierami edukacyjnymi i wsparciem społecznym dla studenta niepełnosprawnego fizycznie w stopniu znacznym. Opracowanie nie jest jednak teoretyczne. Autorka - osoba chora na mózgowe porażenie dziecięce o postaci czterokończynowej, spastycznej, piramidowej i pozapiramidowej naznaczonej ruchami mimowolnymi, a jednocześnie studentka pedagogiki Akademii Pomorskiej w Słupsku - dzieli się bowiem własnymi doświadczeniami.

Dwa artykuły, otwierające trzecią część publikacji, prezentują zagraniczne rozwiązania prawne i pedagogiczne z zakresu resocjalizacji, które mogą stanowić inspirację dla polskiego systemu. Anetta Jaworska opisuje prewencję kryminalną i wspomaganie resocjalizacji sprawców przestępstw w Niemczech, natomiast Justyna Kusztal porusza współczesne problemy resocjalizacji w Republice Czeskiej.

Pozostałe cztery opracowania dotyczą już polskich problemów resocjalizacji. Anna Kieszkowska postuluje zastosowanie w profilaktyce resocjalizacyjnej szerokich działań wspierających jednostki w rozwoju, m.in. budowanie poczucia własnej wartości, określanie celów życiowych, nabywanie umiejętności społecznych, prowadzenie zdrowego try- 
bu życia. Autorka stwierdza na podstawie własnych badań, że pobyt młodzieży w placówkach resocjalizacyjnych nie gwarantuje skutecznych oddziaływań.

Rozwiązania profilaktyczne i resocjalizacyjne w naturalnym środowisku nieletniego proponuje Robert Opora. W oparciu o ekologiczny model profilaktyki uzależnień wskazuje na możliwość kształtowania odporności psychicznej u młodzieży przez interdyscyplinarny zespół specjalistów.

Według Małgorzaty Michel alternatywą dla instytucjonalnych metod profilaktyki i resocjalizacji dzieci i młodzieży jest streetworking, czyli tzw. pedagogika podwórkowa. Praktyczna działalność wychowawcza jest tu prowadzona bezpośrednio na ulicy, podwórku, dając możliwość dotarcia, nawiązania kontaktu, zrozumienia i udzielenia pomocy dzieciom najbardziej zaniedbanym i zagrożonym patologią.

Trzecią część i jednocześnie całą prezentowaną pracę zamyka artykuł Krzysztofa Biela traktujący o resocjalizacji specyficznej grupy młodzieży niedostosowanej społecznie, mianowicie dziewcząt przejawiających zachowania agresywne. Poza teoretyczną analizą zjawiska agresji dziewcząt, autor przedstawia także rozmiary zjawiska według policyjnych statystyk oraz możliwości praktycznych oddziaływań resocjalizacyjnych.

Po lekturze recenzowanej publikacji można stwierdzić, że niewątpliwie spełniony został zamysł redaktorek wzbogacenia wiedzy czytelnika na temat związków teorii i praktyki pedagogicznej. Jednak ocenę czy wiedza ta wpłynęła na jednostkowe postrzeganie rzeczywistości wychowawczej należy pozostawić indywidualnemu czytelnikowi.

Anna Knocińska

\section{Kultura zabawy, pod redakcją Tadeusza Palecznego, Ryszarda Kantora, Magdaleny Banaszkiewicz, Wydawnictwo Uniwersytetu Jagiellońskiego, Kraków 2012, ss. 242}

Trudno sobie wyobrazić życie dzieci i dorosłych bez zabawy. Stanowi ona istotny element ludzkiej egzystencji. Zabawa do niedawna stanowiła mało interesujący temat badawczy, dla wielu była wręcz tematem niepoważnym. Dopiero w ostatnich kilku dziesięcioleciach problematyka zabawy została nobilitowana do ważnych i cennych problemów i stała się dla wielu naukowców - reprezentujących różne dziedziny naukowe poważnym zagadnieniem naukowym ${ }^{1}$. Interdyscyplinarność badań nad zabawą może

${ }^{1}$ Por. m.in. J. Bujak, Zabawki w Europie, Kraków 1988; J. Cieślikowski, Wielka zabawa, Warszawa 1985; K. Kabacińska, Zabawy i zabawki dziecięce w osiemnastowiecznej Polsce, Poznań 2007; Dawne zabawy dziecięce, pod red. D. Żołądź-Strzelczyk, K. Kabacińskiej, Kielce-Warszawa 2008; Dawne $i$ współczesne zabawki dziecięce, pod red. D. Żołądź-Strzelczyk, K. Kabacińskiej, Poznań 2010; A. Brzezińska, Aktywność zabawowa i jej znaczenie dla rozwoju dziecka, w: Nieobecne dyskursy, cz. VI, pod red. Z. Kwiecińskiego, Toruń 2000; R. Caillois, Gry i ludzie, Warszawa 1997; J. Grad, Zabawa - analiza pojęć i koncepcji, „Zabawy i Zabawki” 1997, nr 1-2; J. Huizinga, Homo ludens, Warszawa 1988; U. Kaczmarek, Pedagogika zabawy, „Zabawy i Zabawki" 1997, nr 4; A. Kamiński, Aktywizacja i uspołecznienie uczniów w szkole podstawowej, Warsza- 